Artigos

\title{
0 catolicismo carismático no impeachment de Dilma Rousseff
}

\section{Carlos Eduardo Pinto Procópio}

Resumo: Este artigo analisa o papel dos deputados da Renovação Carismática Católica no processo de impeachment de Dilma Rousseff. A intenção é mostrar as formas de engajamentos e as justificações utilizadas por aqueles deputados. Para tanto, vamos situar suas posições dentro do contexto no qual atuaram, procurando compreender seus engajamentos nas arenas públicas formadas com base na situação problemática do impedimento da presidenta. Com isso, espera-se contribuir com o debate sobre o lugar das denominações religiosas durante essa situação, bem como sobre o debate sobre a presença pública da Renovação Carismática Católica.

Palavras-Chave: Renovação Carismática Católica; Impeachment; Arenas Públicas

\section{The charismatic catholicism in the impeachment of Dilma Rousseff}

Abstract: This article analyzes the role of the deputies of the Catholic Charismatic Renewal in the impeachment process of Dilma Rousseff. The intention is to show the forms of the engagements and the justifications used by deputies. To do so, let us situate their positions within the context in which they operate and understand the models of engagement in public arenas. With this we hope to contribute to the debate on the place of religious denominations in the impeachment of

1 Centro Brasileiro de Análise e Planejamento (Cebrap) e Instituto Federal de São Paulo (IFSP) - São Paulo - Brasil - procopiocso@yahoo.com.br 
Dilma Rousseff, as well as on the debate on the public presence of the Catholic Charismatic Renewal.

Keywords: Catholic Charismatic Renewal; Impeachment, Public Arenas.

\section{Introdução}

A proposta deste artigo é analisar o papel desempenhado pelos principais quadros políticos vinculados ao catolicismo carismático durante o ritual de impeachment de Dilma Rousseff, que selou seu destino político e do projeto que representava. Percorrendo os meandros da participação deste segmento do catolicismo nos momentos finais que antecederam a votação até o seu encerramento no Congresso Nacional, a intenção é mostrar a diversidade dos regimes de engajamento e de justificações de ações que expandem a maneira de ver a atuação política dos carismáticos. Para tanto, faz-se necessário situar suas posições dentro do cenário no qual elas foram executadas, o impeachment e os valores que o constituíram e que foram acionados, para, em seguida, desvelar os conjuntos de força que atravessaram cada atuação dos quadros políticos em análise. Tal tarefa demandará considerar os regimes de engajamento endereçados nas arenas públicas produzidas com base em uma situação problemática (Cefaï, 2002; 2009): o impeachment de Dilma. Com isso, espera-se contribuir com o debate sobre o lugar das denominações religiosas no impedimento da presidenta, bem como com o debate sobre a presença pública de quadros vinculados à Renovação Carismática, cuja atuação na esfera política, ainda que periférica se compararmos com a atuação dos evangélicos, tem chamado a atenção nas últimas duas décadas².

\section{Mobilizando deuses, valorizando famílias e segmentando pertenças}

O Ritual de Impeachment da presidenta Dilma Rousseff (PT) encontrou, na Câmara dos Deputados da República Federativa do Brasil, no dia 17 de Abril de 2016, domingo, seu último ato naquela casa legislativa ${ }^{3}$. Após a abertura dos trabalhos pelo deputado Eduardo Cunha, presidente da referida Câmara,

2 Há uma revisão bibliográfica ampla sobre a presença dos carismáticos na política, que pode ser encontrada em Procópio (2014; 2015). Uma discussão crítica desta participação política, em diálogo com essa literatura, foi retomada recentemente pelo mesmo autor (Procópio, 2018).

3 O processo de impeachment já recebeu alguns tratamentos analíticos por parte das ciências sociais e que se convertem em relevantes materiais para a consulta acadêmica (Ribeiro, 2016; Machado, 2016; Weber et al., 2016; Almeida, 2017; Duarte, 2017; Limongi, 2017; Prandi; Carneiro, 2018). 
seguido do pronunciamento dos líderes das bancadas dos partidos, cada um dos 511 deputados que ocupavam o plenário era convocado para deferir de forma clara e evidente seu julgamento em relação ao processo em curso. Ao fim deste ato, que se arrastou por várias horas, a decisão pelo prosseguimento do processo de Impeachment para o Senado foi aprovado por 367 deputados $(25$ a mais do que o necessário), colocando-se contrário ao prosseguimento do processo o número de 167 deputados, além de 7 abstenções e 2 ausências. Em cada um dos votos a favor, contra ou abstenção, as justificativas dadas pelos deputados versavam sobre as mais variadas coisas, derivada de circunstâncias diversas que endereçaram as tomadas de posição. Dentre as justificativas, chamou a atenção os votos em nome e/ ou em defesa de deus, da família e da região de pertencimento do deputado (Ribeiro, 2016; Almeida, 2017; Duarte, 2017; Prandi; Carneiro, 2018), o que reverberou, quase sempre negativamente, nas capas de muitos dos jornais do país (Weber et al., 2016) e do exterior (Nóbrega, 2016) no dia seguinte à conclusão do Ritual de Impeachment.

Dentre essas reflexões, Duarte (2017) se preocupa em refletir sobre o extenso vocabulário utilizado ao longo das falas durante o ritual de impeachment, expandindo o problema para além dos repertórios religiosos, familistas e localistas utilizados. Nessa direção, além de detectar os sentidos dos usos das palavras família e religião pelos deputados favoráveis e contrários à admissibilidade do processo de impeachment, Duarte apresenta os inúmeros termos operados: Brasil, bandeira, qualidade dos mandatos, partidos políticos, povo, democracia, constituição, estados, golpe, corrupção, ruas, crime de responsabilidade, atores políticos, movimentos sociais, esperança, futuro, honra, categorias profissionais, acusações, honrarias, elogios. Na prática, Duarte sugere que esses termos operaram quase sempre com base na dualidade universalista-particularista. Pelo lado do universalismo, esses termos foram evocados e sentidos como fazendo referência aos dispositivos laicos e impessoais nos quais o Estado estaria assentado. Tal presença na cena pública brasileira não evitou, por outro lado, que elementos particularistas ligados aos vínculos religiosos, familiares e pessoais fossem acionados ${ }^{4}$. Desse modo, a persistência desses vocabulários universalista e particularista na votação do impeachment poderia, segundo Duarte, estar refletindo aspectos mais gerais de um imaginário social que engendra a conduta de deputados no parlamento, sendo a persistência cultural desses elementos

4 Duarte (2017) contabiliza que mais da metade das falas se concentrou em acionar dispositivos que chamou de universalistas. 
o que ajudaria a entender os sentidos que teriam atravessado cada uma das falas colocadas e a maneira como elas foram recebidas pela população.

Almeida (2017), no que tange às reflexões sobre a evocação de deus, família e região no impeachment, concentrou-se em decifrar, durante a votação, o que chamou de as faces de deus no parlamento. Para este antropólogo, esses termos que compuseram o léxico político na ocasião, serviram como "elementos unificadores e transversais", estabelecendo linhas de força, chegando a possuir mais densidade do que os termos do repertório político liberal moderno, como democracia, estado de direito e cidadanias. De acordo com Almeida, essas linhas de força colocaram deus como signo de poder, revelando o valor histórico-cultural do cristianismo no país, seja quando acionado na abertura dos trabalhos da Câmara ou quando utilizado como operador das transformações na política brasileira. Deus também aparece como elemento de distinção, utilizado para contrastar com aqueles que apoiam o inimigo em comum, o PT de Dilma Rousseff, demonizado e que precisava ser destruído. Outra forma de deus que Almeida encontrou foi aquele que passava pela valorização dos bens com correspondência divina, a família e os valores morais, que estariam ameaçados e precisavam ser defendidos. Mas também emergiu outro deus, agora na fala dos que tomaram a menção a esta figura religiosa no parlamento como descabida e despropositada, que antes de ser utilizada em uma acepção ético-moral deveria ser praticada no seu sentido político-caritativo. A esta última forma Almeida chamou de "deus derrotado" que, além de contrastar com as anteriores, acabou encontrando menor capilaridade junto aos parlamentares que lançaram mão de alguma justificativa de cunho religioso.

Prandi e Carneiro (2018) se esforçaram para agrupar os itens identificados ao longo da votação do impeachment em eixos que expressavam as linhas de força que atravessaram o processo que levou ao afastamento de Dilma. Os autores conseguiram alinhar os vários itens publicizados na sessão da Câmara em 5 eixos: democracia; bom governo e programas sociais; mau governo e corrupção; legalidade; tradição ${ }^{6}$. Em seguida, inclinam-se para os votos a favor e contra o

5 Almeida identificou que dentre os 367 deputados que votaram a favor do impeachment, o termo deus aparece 43 vezes, enquanto o termo família aparece 117 vezes e nação 28 vezes. Já entre os 137 deputados que votaram contra o impeachment, deus aparece apenas 7 vezes, família 10 vezes e nação 4 vezes.

6 De acordo com Prandi e Carneiro (2018, p. 11), "alinham-se no eixo da democracia os itens "legalidade", "democracia", "trabalhadores" e "os que sofreram sob a ditadura". Compõe a dimensão bom governo e programas sociais os itens "bom governo", "marginalizados sociais", "retomada do desenvolvimento". O mau governo e a corrupção, por sua vez, está associado mais fortemente aos itens "contra Lula e o PT", o "mau governo da presidente", a "voz das ruas" e a "corrupção". O quarto fator, que se denominou legalidade, inclui os itens "pela liberdade e justiça", "pela Constituição" e "pelo povo brasileiro". A quinta 
impedimento da presidenta, mostrando que os votos contrários ao processo de afastamento passavam majoritariamente pelos eixos democracia, bom governo/programas sociais e legalidade, enquanto que os votos favoráveis passavam, em grande parte, pelos eixos mau governo/ corrupção e tradição. A análise fica ainda mais interessante quando os autores vão olhar para a votação da bancada evangélica, cujos deputados favoráveis ao impeachment chagaram na casa dos $93,80 \%$, que representa $22 \%$ acima da média de todos os demais deputados que votaram sim. No caso daqueles deputados, o eixo tradição vai ser aquele pelo qual vai passar a maioria das justificativas dos votos (70\%), ficando o eixo democracia do lado oposto, ou seja, como eixo no qual as justificativas menos estiveram assentadas (14\%). Como conclusão, Prandi e Carneiro procuram ressaltar que o papel da religião no impeachment expressou os valores tradicionais que ela defende. Por mais que esses valores encontrassem correspondência com as justificativas de outros deputados não evangélicos e que votaram a favor do afastamento de Dilma, os evangélicos o fizeram com mais ênfase. A presença política dos evangélicos, segundo os autores, a despeito dos acordos e conchavos que se esconde por trás de cada voto, só consegue ser feita pelas vias da tradição, pela sua justificativa "em nome do pai: Deus, a igreja, a família, o país, seu lugar e aqueles que o habitam" (Prandi; Carneiro, 2018: 19).

Além desses casos mais gerais analisados por Duarte, Almeida e Prandi e Carneiro, cabe frisar que, dentre as justificativas apresentadas no Plenário da Câmara dos Deputados, como mostrarei adiante, duas delas chamaram a atenção pela invocação do pertencimento à Renovação Carismática Católica . Essas posições poderiam ser tomadas, seguindo Duarte (2017), como uma expressão dos valores particularistas que estariam assentadas no interior dos segmentos carismáticos citados. Mostraria um deus nas suas faces distintivas e valorativas, cujos princípios que encarnava deveriam ser defendidos, como mostrou Almeida (2017). Mas também expressaria a defesa da tradição, feita em nome de deus e das instituições que encontrariam nele uma correspondência, conforme tematizado por Prandi e Carneiro (2018). Parte da literatura sobre a relação entre carismáticos e política também responderia bem a esta presença política, se pudéssemos resumir a atuação política dos carismáticos àquelas falas. $\mathrm{O}$ engajamento dos carismáticos poderia estar refletindo um rosto básico do movimento,

dimensão reúne igreja, Deus, a instituição da família, a família do deputado, a base eleitoral do deputado e o país. Não podia deixar de ser chamada de tradição". [grifos meus].

7 Votaram em nome do movimento carismático os deputados Diego Garcia (PHS/PR), que votou em nome do Projeto (Ministério) Fé e Política, e Eros Biondini (PROS/MG), que votou em nome da comunidade Canção Nova. 
conservador em termos morais e éticos e preocupado em marcar posições políticas mais à direita da vida política (Portella, 2011). Mas também justificaria uma presença intransigente e até certo ponto indevida, ao confundir a atuação política com atuação religiosa, desconsiderando os meandros da atividade parlamentar e marcando uma presença pública por meio do proselitismo católico (Prandi, 1996; 1998; Carranza, 2000).

Contudo, a participação deste movimento católico no processo de Impeachment, pelo menos em termos de engajamento de seus principais quadros políticos, não pode ser resumida à justificativa do voto a favor ou contra a admissibilidade do processo de impedimento de Dilma baseada na estandardização de seus vínculos religiosos. Nesse sentido, olhando mais de perto para o problema levantando, é possível ver a questão das relações entre catolicismo carismático e política no contexto da representação parlamentar, especificamente na Câmara dos Deputados, para além do que indica a posição dos dois deputados que votaram em nome do catolicismo carismático durante o Ritual do Impeachment. Assim, será possível visualizar um cenário muito mais amplo, mostrando as polifonias da presença política de grupos como os da Renovação Carismática Católica na esfera parlamentar (Procópio, 2018). Ao manifestarem publicamente suas posições no jogo do impeachment, nos púlpitos, nas ruas, nos encontros ou nos partidos, os deputados do carismatismo católico apontam para conjuntos de forças que ajudam a entender os sentidos que atravessam a política deste movimento católico.

Desse modo, é preciso olhar para o próprio ato final do Ritual de Impeachment na Câmara dos Deputados, onde outros parlamentares, também vinculados à Renovação Carismática Católica, estavam presentes. Mas também é preciso olhar para alguns nomes com projeção política ligada a este movimento que, por opção ou circunstâncias, não estavam presentes no desfecho do ritual. Essas personagens até então possuíam visibilidade enquanto quadros políticos do catolicismo carismático, e que ajudam a sinalizar para outros regimes de engajamento desse agrupamento religioso na política. Tanto os deputados que votaram em nome do movimento católico quanto os que se posicionaram a favor ou contra o impeachment de outras maneiras, devem ser observados em diálogo com as estratégias eleitorais e parlamentares de cada um deles, mas também com as pressões e mobilizações coletivas e partidárias na qual estão inseridos. Desse modo, podemos ver modelos de inserção e ação política distintas, que acabarão dando vazão a uma compressão muito mais alargada para aquilo que os carismáticos católicos querem e fazem na política. 
Tomar a posição dos carismáticos no impeachment nesse sentido mais expandido, situando suas ações dentro de conjuntos de forças que os atravessam, coloca o problema do engajamento desse agrupamento dentro do debate sobre a emergência de arenas públicas. Ao se apresentar como o que Cefaï (2002) chamou de situação problemática, o processo de impedimento de Dilma permitiu que vários atores se mobilizassem diante da questão, publicizando performances e endereçando soluções. Nesse momento, os dispositivos de ação e enunciação estavam circunscritos a enredos que se davam desde a formação e aprendizagem política de cada deputado, a existência de grupos de pressão formados por bases eleitorais, público em geral e formadores de opinião, os interesses classistas aos quais estariam vinculados e as articulações partidárias desenvolvidas até o momento. Enquanto arena pública, seguindo a definição de Cefaï (2002; 2009), os engajamentos a partir do impeachment fazem com que agrupamentos sejam modelados, aglutinando conjuntos de força, operando dramatizações e mobilizando retóricas que, antes de orientados antecipadamente, são desenvolvidos ao longo de um jogo que leva em conta expectativas em relação ao que foi e deverá ser feito. Por conta disso, a movimentação dos deputados carismáticos no impeachment está muito longe de poder ser tomada como uma única ação ordenada e homogênea, mas, ao contrário, como atravessada por motivações e interesses diversos que estão colocados na prática cotidiana de suas experiências na vida pública.

\section{Os carismáticos do Impeachment ${ }^{8}$}

A composição da Câmara dos Deputados que levou a cabo o Ritual de Impeachment do dia 17 de abril foi eleita durante o processo eleitoral de 2014, tendo sido considerada pelos analistas do DIAP (2014) a legislatura mais retrógrada desde a reabertura democrática dos anos de 1980, levando em conta os nomes e propostas dos candidatos eleitos. Dentre os deputados eleitos, pelo menos seis deles tinham algum tipo de relação com a Renovação Carismática Católica (RCC), desde um vínculo direto com grupos e comunidades até a simpatia e reconhecimento de seu nome junto a estes espaços de sociabilidade carismáticos: Alessandro Molon (PT/RJ); Diego Garcia (PHS/PR); Eros Biondini (PROS/MG);

8 Tomei como as principais referências do catolicismo carismático na política durante o processo de impedimento de Dilma aqueles quadros que tinham ou passaram a ter projeção a partir das eleições de 2014. Além dos deputados federais eleitos e em exercício, incluí outros três que, apesar de não ocuparem cargo parlamentar durante o impeachment, ocupavam posição política significativa na condição de secretários de governo. 
Evandro Gussi (PV/SP); Flávio Augusto da Silva, o Flavinho (PSB/SP); Odair Cunha (PT/MG). Esses políticos desempenharam papéis diferentes na disputa pela permanência ou retirada de Dilma Rousseff da presidência.

Molon, advogado, foi radialista em uma rádio católica e, apesar de não se declarar abertamente como sendo do movimento carismático, é nome constante nas listas de apoio político da RCC carioca e tem votos em regiões com atuação desse movimento. Foi reeleito como deputado do PT, mas mudou de legenda em setembro de 2015, filiando-se à REDE depois de ter ficado na sigla que o elegeu por quase 16 anos. Diego Garcia estava na sua primeira legislatura. É militante orgânico da RCC paranaense, participando de pregações e eventos e contou com sua atuação junto ao Projeto (Ministério) Fé e Políticas como capital político para a conquista do mandato. Biondini, cantor católico, atuava em comunidades carismáticas na região central de Minas Gerais e se encaminhava para seu segundo mandato no Congresso Nacional. Estava filiado ao PROS, após ter passado pelo PHS (2005-2009) e pelo PTB, partido pelo qual foi eleito em 2014. Gussi era professor de direito, advogado e estava em seu primeiro mandato. Além de atuante na RCC de sua região, o oeste paulista, participava de programas jornalísticos da Comunidade Canção Nova1o. Flavinho também estava em seu primeiro mandato e sua fama no movimento carismático advinha de sua circulação como cantor, especialmente nos eventos do Padre Jonas Abib, da Canção Nova. Odair, que se encaminhava para sua terceira legislatura, foi radialista e advogado e participava como pregador em eventos da RCC no Sul de Minas, onde frequentou comunidades carismáticas11 em Três Corações e Pouso Alegre. Odair se licenciou tão logo foi empossado no mandato em 2015

9 O Projeto (Ministério) Fé e Política, criado em meados dos anos de 1990, compõe um dos braços da RCC no Brasil, que tem como intenção produzir discernimento sobre o voto junto à comunidade carismática e sugerir uma lista de nomes afinados com a programática católica, especialmente em termos morais e éticos. Algumas dinâmicas desse Ministério podem ser encontradas nos trabalhos de Carranza (2000) e Procópio (2014). Os limites da atuação desse Ministério podem ser encontrados no trabalho de Miranda (2016). É importante frisar que o Ministério Fé e Política da RCC tem diferenças em relação ao modelo do Movimento Nacional de Fé e Política, atrelado às Comunidades Eclesiais de Base (CEBs). Um panorama sobre este último pode ser visto na coletânea organizada por Ribeiro de Oliveira (2005). Apesar das diferenças, podemos encontrar algumas ligeiras influências do modelo liberacionista sobre o modelo carismático, como mostrou Procópio (2014).

10 A Comunidade Canção Nova é uma comunidade católica fundada em 1978, com sede em Cachoeira Paulista (São Paulo). Possui um sistema de rádio e televisão de longo alcance, que cobre todo o território nacional. Dentre os trabalhos que dão conta de apresentar as características dessa comunidade, destaca-se o de Oliveira (2009).

11 As diversidades das comunidades carismáticas no Brasil foram apresentadas e debatidas na coletânea organizada por Carranza, Camurça e Mariz (2009). 
para assumir a função de Secretário de Estado em Minas Gerais, que passaria a ser governado pelo petista Fernando Pimentel.

Além desses deputados eleitos, é significativa a tentativa de Salvador Zimbaldi (PROS/SP) em conquistar o seu quinto mandato como deputado federal. Foi militante orgânico da RCC desde os anos de 1980, fazendo com que seu nome fosse um dos mais exaltados por algumas alas no catolicismo carismático, por conta de seu empenho em defender abertamente as bandeiras conservadoras que atravessam o referido movimento. Entretanto, seus 65.641 mil votos não foram suficientes para que ele pudesse compor a legislatura a ser iniciada em fevereiro de 2015, ficando na condição de suplência. Outro caso de deputado ligado ao catolicismo carismático e que não pode ser negligenciado é o de Gabriel Chalita (PMDB/SP; PDT/SP), afamado como escritor e educador no interior do movimento carismático, bem como de alguns setores médios paulistas, que tinha decidido não concorrer à reeleição em 2014. Sua ausência deixou uma lacuna para o movimento católico, que tinha nele uma aposta de vitória certa, sobretudo levando em conta sua projeção eleitoral anterior (2010), quando ele obteve cerca de 560 mil votos.

Após ser iniciada a convocação dos deputados para proferirem seu julgamento sobre o parecer que sugeria a admissibilidade do processo de impeachment, e na medida em que as posições tomavam forma e as faces de quem votavam contra ou a favor do relatório eram delineadas, acordos, articulações e traições puderam ser provados. Por trás do resultado final que selou o destino político de Dilma, que a história do tempo presente adjetiva como golpe (Singer, 2016; Souza, 2016), muitas tramas foram tecidas e os deputados ligados ao catolicismo carismático não estiveram ausentes nas mesas de negociação e nem deixaram de sofrer pressões externas para se inclinarem para um lado ou para o outro na disputa.

Para dar conta dos engajamentos dos carismáticos nesse momento da história política do país, veremos em três atos como seus principais quadros políticos participaram do processo de impeachment: o primeiro ato percorre as dinâmicas em torno dos deputados que votaram em nome da Renovação Carismática; o segundo ato procura compreender a posição dos demais deputados ligados ao carismatismo católico, que lançaram mão de outros dispositivos no endereçamento do voto; o terceiro ato se debruça sobre a atuação dos demais políticos carismáticos que ainda possuíam projeção na esfera política mas que não estavam presentes durante a votação.

A invocação do pertencimento ao movimento carismático apareceu em dois momentos ao longo do Ritual de Impeachment. Primeiro no pronunciamento 
de Diego Garcia, o $86^{\circ}$ deputado convocado para pronunciar sua decisão, filiado ao PHS/PR, que votou "sim" pela admissibilidade do processo pela Câmara. O segundo aparece na fala de Eros Biondini, $381^{\circ}$ deputado convocado para pronunciar seu voto, filiado ao PROS/MG, que também votou "sim" pela admissibilidade do processo pela Câmara.

Sr. Presidente, fui eleito por paranaenses que acreditam no resgate da moralidade na política. Fui eleito pelo Projeto [Ministério] de Fé e Política da Renovação Carismática Católica no meu Estado do Paraná. Pela minha família, pela minha filha, pela minha esposa, pelo povo do Paraná, tenho orgulho em dizer: terra da Lava-Jato, avante! Polícia Federal! Sim ao impeachment. [grifos meus]. [Diego Garcia]

Sr. Presidente, pelos valores que herdei dos meus pais, e que procuro repassar aos meus filhos; pela gratidão que tenho à Renovação Carismática Católica, à Canção Nova e aos demais movimentos que me ajudaram a me livrar das drogas; pelos milhões de brasileiros que vivem hoje nas drogas e não têm ajuda; para honrar os belorizontinos, os mineiros, os brasileiros nesta Terra de Santa Cruz, o meu voto é sim. E o voto do meu suplente, Euclides, também seria sim, Sr. Presidente. [grifos meus]. [Eros Biondini]

Dentre o conjunto de deputados que votaram a favor do impeachment, Diego Garcia e Eros Biondini foram os únicos que mencionaram na sua decisão seus vínculos com instituições católicas, particularmente com a Renovação Carismática Católica, sendo agregado na justificativa do primeiro o vínculo com o Projeto (Ministério) Fé e Política e agregado na justificativa do segundo seu vínculo com os movimentos carismáticos, especialmente com a Comunidade Canção Nova. A posição desses deputados, apesar de serem ínfimas em relação ao montante das declarações, revela uma ligação entre religião e política na arena pública, especialmente a relação entre catolicismo carismático e política, que vem sendo debatida na reflexão acadêmica sobre o tema, conforme mostra revisão realizada em Procópio (2014). Garcia e Biondini estariam dando vazão para um projeto religioso-político que quer marcar a cena política brasileira, particularmente na Câmara dos Deputados, com valores e elementos condizentes com as demandas que acreditam suas instituições de origem possuir, que passam principalmente pela valorização dos princípios das instituições religiosa e familiar. Nesse sentido, ao justificarem suas decisões em relação à admissibilidade do processo de impeachment da presidenta da República brasileira, fazendo menção a seus pertencimentos religiosos, estariam marcando 
uma posição para estas instituições na cena política e, ao mesmo tempo, dando indícios de que, ao serem colocados como representantes legítimos destas instituições, suas decisões seriam a ressonância de um projeto mais amplo ${ }^{12}$.

Enquanto apenas os deputados Diego Garcia e Eros Biondini mencionaram seus vínculos com o catolicismo carismático, outros três deputados carismáticos presentes não utilizaram este vínculo no proferimento de suas decisões. Evandro Gussi (206 convocado) votou "sim", tal como Flavinho (208 convocado), enquanto Alessandro Molon ( $295^{\circ}$ convocado) votou "não":

Sr. Presidente, este é o momento de silenciarmos a nossa voz e o nosso coração e de ouvirmos a voz que vem das ruas inundadas de verde-amarelo no Brasil. A favor do Brasil, por São Paulo, especialmente, do seu oeste, Sr. Presidente, eu voto sim e registro aqui que o Deputado Mendes Thame, suplente nesta ocasião, se aqui estivesse, também votaria sim, Sr. Presidente. [grifos meus]. [Evandro Gussi].

Cumprindo a minha obrigação constitucional de legislador e de fiscalizador, eu acolho a denúncia dos juristas que foi apresentada contra a Presidente Dilma Rousseff. Também, fazendo um julgamento político, creio que não é o melhor Governo para este País. Mas, Sr. Presidente, com todo respeito institucional que tenho por V. Exa., espero que também esta Casa tenha a coerência de fazer com que o processo contra $V$. Exa. progrida, para que esta Casa também seja passada a limpo. Pelo Brasil, pelo meu Estado e pela honra da minha família, eu voto sim. [grifos meus]. [Flavinho].

Porque prometi defender a Constituição quando cheguei a esta Casa, porque não há crime de responsabilidade no parecer do Relator, porque respeito o voto do eleitor brasileiro e porque luto pela democracia no meu País, meu voto convicto é não. [grifos meus]. [Alessandro Molon].

Essas posições apontam para um tipo diferente de engajamento dos deputados com algum vínculo com a Renovação Carismática Católica, diminuindo o alcance da tese da intransigência, esboçada por autores como Prandi (1998) e Carranza (2000), que seria inerente à presença política de atores vinculados a

12 Houve questionamentos sobre a posição desses deputados por parte de vários carismáticos. O dia posterior à votação do impeachment levou com que muitos adeptos e simpatizantes do movimento usassem as redes sociais virtuais de comunidades e grupos para demonstrarem sua insatisfação com a conduta dos deputados que votam em nome da RCC. Não houve uma posição oficial, por meio de nota ou manifestação pública, do Conselho Nacional da Renovação Carismática e nem da Canção Nova em relação ao impeachment. As posições abertas a favor ou contra acabaram sendo uma opção particular que quem emitia a declaração. O mesmo vimos em relação à $C N B B$. 
esse movimento na esfera política parlamentar. Gussi tomou sua decisão orientada por parte das ruas que se cobriram de verde e amarelo, especialmente nas grandes cidades centro-sulistas brasileiras, mas também pela vontade política de seu estado, em particular sua região de origem, o oeste paulista. Flavinho indicou sua decisão levando em conta o parecer da Comissão do Impeachment, que acolheu a denúncia contra a presidenta e encaminhou o processo para votação no plenário. Por outro lado, agregou à sua decisão a certeza de que Dilma não era a mais capacidade para estar a frente do governo federal, finalizando o voto acentuando seu compromisso com a defesa do país, de seu estado e de sua família. Molon, tendo por base o relatório mencionado por Flavinho, tomou posição contrária, por não ver neste documento crime de responsabilidade que justificaria o impeachment. Agregou à sua decisão o respeito que se deve ter pelos votos que elegeram a presidenta e os valores democráticos que deveriam ser defendidos, valores estes que estavam sendo ameaçados, conforme repertório político dos membros dos então partidos governistas.

A este panorama da ação dos deputados ligados ao catolicismo carismático podem ser acrescentadas algumas mobilizações envolvendo Salvador Zimbaldi, Gabriel Chalita e Odair Cunha em relação ao processo em curso e que, mesmo não culminando em voto físico no plenário da Câmara, dá ao analista a possibilidade de compreender a polifonia da relação entre catolicismo carismático e política. Zimbaldi, que não havia sido reeleito em 2014, e certamente por sua ligação com a regulamentação do Circuito Religioso do Vale do Paraíba, que incluía Aparecida do Norte, Cachoeira Paulista e Guaratinguetá ${ }^{13}$, acabou assumindo em setembro de 2015 a Secretaria Especial de Assuntos de Turismo da Prefeitura de São Paulo, cujo prefeito era Fernando Haddad (PT), vinculado ao partido da presidenta. Na época do processo de votação do impeachment, ele não se pronunciou abertamente sobre o caso, mas seu filho e herdeiro político, Rafael (Rafa) Zimbaldi, vereador em Campinas pelo PP/SP, suplente de deputado estadual e membro da RCC, foi um proeminente defensor da consumação do processo de impeachment e também divulgador assíduo de chamadas nas redes sociais convocando para mobilizações virtuais e presenciais, especialmente em sua cidade de origem.

13 O Circuito Religioso do Vale do Paraíba é assim denominado desde a aprovação do projeto de Lei $\mathrm{n}^{\circ}$ 646/2008 em 2009 na ALESP, que concedeu às cidades de Aparecida, Cachoeira Paulista e Guaratinguetá um estatuto especial no âmbito turístico do Estado de São Paulo. Por serem cidades de peregrinação religiosa, elas atraem centenas de milhares de devotos anualmente e que, com a aprovação do Projeto de Lei, passaram a ter benefícios específicos do Governo do Estado. 
Chalita, que abriu mão da disputa em 2014, acabou assumindo a Secretaria de Educação da Prefeitura de São Paulo em 2015, passando a fazer parte da gestão de Fernando Haddad, de quem seria candidato a vice-prefeito nas eleições de outubro de 2016. Seus vínculos estabelecidos ao longo do último ano acabaram levando o então Secretário da Educação a se posicionar ao lado daqueles que se contrapunham ao impeachment, chegando inclusive a se desfiliar do PMDB/SP, no qual estava vinculado desde 2011, para retornar ao PDT/SP, primeiro partido de Chalita, quando se elegeu vereador em Cachoeira Paulista/ SP no fim dos anos 1980.

Odair Cunha, por sua vez, sendo deputado federal eleito pelo PT, mas logo se licenciando para assumir a Secretaria de Estado de Minas Gerais, teve sua exoneração do cargo encaminhada a pedido do seu partido, nas vésperas da votação do ato final do ritual de impeachment, para que retornasse à Câmara e votasse com seus pares em defesa da presidenta Dilma. Entretanto, a exoneração foi abortada por ser avaliada como desnecessária, uma vez que sua presença não alteraria o número de votos dos deputados do Estado de Minas Gerais já declarados em favor do governo federal.

\section{Altar, rua, democracia e partido}

Diante do panorama exposto sobre a atuação dos quadros políticos vinculados ao catolicismo carismático no ritual do impeachment, é possível assinalar alguns conjuntos de força que foram colocados em jogo e que ajudam a pensar algumas dinâmicas nas quais o carismatismo católico se viu envolvido quando da sua participação em uma arena política representativa. Mesmo sendo limitado o alcance das projeções, por conta do recorte realizado por este artigo, estes conjuntos de força podem ajudar a expressar os contextos pelos quais os engajamentos são produzidos, bem como os moduladores das performances que lançam mão para endereçarem suas perspectivas e demandas. Os carismáticos querem dizer alguma coisa quando se direcionam para um lado ou para outro na disputa do impeachment, tomando posições e direções diversas quando se movimentam ou se deixam movimentar sob a trama na qual eles se veem obrigados a atuar.

As posições de Diego Garcia e de Eros Biondini, que justificaram seus votos em nome da Renovação Carismática Católica e, respectivamente, em nome do Projeto (Ministério) Fé e Política e da Canção Nova, sinaliza um primeiro conjunto de forças. Este estaria privilegiando o próprio espaço religioso no qual realizam parte de suas vidas ordinárias, colocando suas posições como 
representativas de todo grupo ou comunidade. O que está colocado na posição desses deputados é uma tentativa clara de dar evidência ao nome do movimento do qual participam e uma tentativa de produzir uma afinidade deste com uma posição favorável ao impeachment. Não é novidade para a literatura corrente sobre carismáticos e política a posição de alguns políticos que, alçados a esfera parlamentar, decidem promover seu movimento de origem (Prandi, 1996; 1998; Miranda, 1999; Carranza, 2000), o que igualmente o fazem políticos de outros movimentos cristãos (Machado, 2005; Machado; Burity, 2006). Para o caso dos carismáticos, a pertença religiosa acaba condicionando uma atuação parlamentar que procura em grande parte atender às demandas políticas e sociais do grupo de origem, especialmente em termos éticos e morais e a concessão de sinais de rádio e televisão e de títulos de utilidade pública (Reis; Almeida, 2015). O que deve ser acrescido nessa reflexão é que, mesmo não sendo novidade na esfera parlamentar, alguns quadros políticos tomam suas posições particulares como a posição de todo grupo, apresentando uma pretensa unidade deste em torno de uma posição e deslocando-o para um dos lados da disputa. Por mais que possam encontrar respaldo em parte das bases pelas quais dizem falar, não é sem resistência que vão promover o seu intento.

Garcia, ao associar seu voto ao Projeto (Ministério) Fé e Política e marcar para este setor do carismatismo católico uma posição em relação ao impeachment, rompe com a neutralidade que o Ministério sempre cultivou e pode estar sinalizando para uma disputa no seu interior. Mesmo que apoie candidaturas a deputado, dentro de uma plataforma de identificação mínima, o Ministério, enquanto organização, costuma manter-se em consonância com as posições oficiais da Renovação Carismática e da Igreja Católica em geral, que prega cautela e responsabilidade na tomada de posições políticas (Procópio, 2014) ${ }^{14}$, como foi o caso do impeachment. Apesar de sua posição cismática, Garcia tem a seu favor o fato de que inaugura um tipo de promoção de candidatura em nível estadual, que tem na inserção em grupos de oração de todo o estado um capital eleitoral significativo. Se este modelo passar a servir como o mais efetivo para o movimento carismático, porque produz campanhas mais homogêneas em nível de discurso e não depende de grandes comunidades ou acordos com outros agrupamentos para a conquista de um cargo parlamentar, o Ministério vai se

14 Miranda (2016) tem afirmado que o Ministério Fé e Política não consegue, em algumas ocasiões, legitimidade disciplinadora ou mesmo normatizadora, levando as candidaturas que reivindicam o lugar de fala do movimento carismático a atuarem com muita autonomia. Mas o recurso ao referido projeto pode ter um uso retórico capaz de modelar ações e procedimentos que modificam sua presença pública, tal como demonstra o caso de Garcia. 
defrontar com o dilema de ter que criar diretrizes mais claras e aceitar programas ideológicos mais exclusivistas ${ }^{15}$.

Já Biondini, por sua vez, ao dar visibilidade para a Canção Nova em seu voto, mobiliza um conjunto de acontecimentos ocorridos no interior dessa comunidade em relação à pessoa da presidenta em julgamento. Foi na Canção Nova que o tradicionalista Padre Paulo Ricardo, afamado por falar contra Dilma dezenas de vezes ao longo dos últimos anos, ganhou espaço (Silveira, 2015). É também nessa comunidade que germinou o movimento Acorda Canção Nova, cuja face reacionária permitiu com que se aglutinassem aqueles que viam em Dilma uma personagem contrária aos valores cristãos (Andrade; Sofiati, 2014). Nesse sentido, a posição de Biondini estaria encontrando uma justaposição com algumas posições da própria Canção Nova, apesar desta não ter se posicionado abertamente em relação ao impeachment. Contudo, não se pode deixar de considerar que, nas franjas dessa comunidade, as críticas à sua evocação no voto do deputado se fizeram presentes. No dia seguinte à votação do impeachment, o site da Canção Nova amanheceu repleto de posições contrárias à ação de Biondini, que, segundo alguns internautas, teria indevidamente falado por toda uma comunidade, desconsiderando os muitos pontos de vista que a atravessam.

A posição de Evandro Gussi, ao procurar um diálogo com as ruas, votando em nome desta, sinaliza para um segundo conjunto de forças. Os estudos antropológicos e sociológicos sobre as manifestações de rua, ao longo do período que ganhou seu ápice na votação do impeachment no Congresso Nacional, são categóricos em mostrar as diferenças e os tipos de repertórios utilizados pelos agentes envolvidos (Gohn, 2016; Alonso, 2017; Pinto, 2017 $7^{16}$ ). De um lado estariam os agrupamentos tradicionalmente vinculados à esquerda, como os sindicatos, sociedade civil organizada, agremiações estudantis, intelectuais e artistas, que se aglutinavam em dias alternados da semana e cuja posição oscilava entre a defesa direta da presidenta e o apelo pela conservação dos valores

15 Esta prática é bem visualizada em eleições para os legislativos municipais em cidade de pequeno e médio porte, quando o movimento carismático fecha o apoio a um candidato e consegue arregimentar eleitores em torno de uma proposta de ação (Miranda, 1999; Silveira, 2008; Silva, 2008). A ampliação dessa prática para o nível estadual e federal, entretanto, ainda está em gestação. Casos como Diego Garcia são pontuais e demandam menos concorrência interna para serem efetivadas, o que é justamente o oposto do que se vê em estados como São Paulo e Minas Gerais, que conhecem um leque de nomes e projetos oriundos desde o interior de grupos e movimentos carismáticos. Essa diversidade tem sido tematizada em Procópio (2012; 2014; 2015).

16 Enquanto Gohn e Pinto estão preocupadas em descrever os acontecimentos e apreciar a qualidade dos engajamentos do período, Alonso se interessa em compreender o que ela chama de ciclos de confronto, levando em conta os repertórios acionados e as suas direções. 
democráticos e da Constituição republicana brasileira. Do outro lado estariam os agrupamentos inclinados para a direita política, que tomavam Dilma e seu partido como a personificação de toda a corrupção do país e que, por isso, deveria ser banida. Ocupando as regiões centrais das principais cidades do centro-sul do Brasil nas manhãs e tardes de domingo, tomaram o verde e amarelo como cores de sua revolta, tendo suas posições e demandas marcadas por uma pertença vinculada à classe média tradicional. É a este último agrupamento que o voto de Gussi está associado e suas posições podem estar comungadas com as demandas desses atores políticos que desempenharam papel importante no jogo do impeachment ${ }^{17}$.

Ao votar em nome das ruas inundadas de verde e amarelo, Gussi deixa clara sua posição e por quem está falando. Por mais que possa não comungar de todas as bandeiras colocadas em movimento, este deputado não deixa de dialogar com o corte classista que atravessa aqueles engajamentos públicos. Os estudos sócio-antropológicos sobre o catolicismo carismático sustentaram, durante muito tempo, o perfil classe média e conservador em termos éticos e políticos dos frequentadores dos grupos de oração e comunidades ligadas à Renovação (Oliveira, 1978; Oro, 1996; Prandi, 1998; Carranza, 2000; Valle, 2004). Esse perfil, em parte, foi identificado nas ruas pelas sondagens realizadas por vários jornais do país (Pimentel Jr, 2015), o que pode revelar o mimetismo entre o ideário das ruas e o ideário dos católicos carismáticos. Claro que não convém exagerar, porque o perfil dos carismáticos não os levam automaticamente para a direita política, mas é possível que exista uma identificação classista que vai culminar na posição de políticos como Gussi, que se reconhecem e se engajam como parte de um grupo que carrega valores e formas de organizar o mundo da vida e da política.

Outra linha de força está representada por Salvador Zimbaldi, que optou por não se engajar abertamente sobre a questão, que certamente o fez porque desejava manter uma boa relação com o partido da presidenta, que lhe abriu espaço na secretaria de turismo da prefeitura de São Paulo. Não se engajar favoravelmente ou contra permite que resguarde sua posição diante daqueles com os quais convivia no âmbito da prefeitura, que eram contrários ao impedimento, mas também diante daqueles que faziam parte do seu círculo religioso e que eram favoráveis ao afastamento de Dilma, setor pelo qual seu filho Rafa procurou representar com uma posição favorável ao impeachment. Essa relação,

17 Na mesma direção pode ser lida a atuação de Rafa Zimbaldi, filho de Salvador Zimbaldi, que optou, apesar da omissão do pai, em se engajar nas ruas em prol do impeachment. 
instrumental, não é novidade no interior do movimento carismático e sua relação com a esfera da política. Carranza (2000) mostrou essa faceta do movimento quando sinalizou que o que importa para os católicos carismáticos é ter acesso a recursos do estado que pudessem viabilizar seus projetos, que estariam sempre para além de interesses político-ideológicos e programático-partidários mais amplos. No mesmo sentido vai a reflexão de Iffly (2011), que comentou a tensão de Salvador Zimbaldi e Osmânio Pereira e o PSDB, partido em que estavam filiados e pelo qual eram deputados em 2003, quando ambos decidiram apoiar o governo Lula, do PT. Na ocasião, os deputados optaram por abandonar o partido ao qual estavam vinculados e manter seu alinhamento com o novo conjunto de forças que ganhava hegemonia. Essa tensão mostra mais uma vez uma faceta instrumental do carismatismo, na medida em que o que importa é circular próximo dos grupos e pessoas que podem facilitar acesso a recursos do estado. $\mathrm{O}$ caso de Zimbaldi durante o impeachment é emblemático, porque uma secretaria de turismo não poderia ser desconsiderada com facilidade. Existem muitas atividades desse movimento católico na área do lazer e do entretenimento que dependem do acesso a espaços como a secretaria que Zimbaldi ocupava.

As posições de Flavinho e Alessandro Molon, apesar de terem apontado para resultados diferentes, partem do respeito pelos dispositivos democráticos como justificativa central dos seus votos. Flavinho justifica seu voto articulando sua posição como legislador e fiscalizador com o fato de estar fazendo um julgamento que também é político, o que o leva a acolher a denúncia contra Dilma. Nesse sentido, reconhece os limites de sua função e procura valorizar o procedimento, quando tem no relatório em votação o norteador de sua decisão. Por outro lado, ao exigir o mesmo tipo de julgamento para Eduardo Cunha, reconhece que o combate aos crimes de responsabilidade, matéria do relatório contra a presidenta, deve ser tomado como parte de um processo mais amplo e que recairia sobre qualquer representante que se desviasse de seu compromisso com o bem público. Molon, por sua vez, toma o relatório como prova de inexistência de crime de responsabilidade, vota não e aponta para a necessidade de se valorizar a Constituição, o sufrágio e a democracia. Sua posição toma uma direção em diálogo com aqueles que acreditavam que o impeachment colocava em jogo um conjunto de dinâmicas para além de resumir a questão do impedimento a um crime de responsabilidade.

O reconhecimento dos dispositivos democráticos tem sido considerado nos trabalhos recentes sobre catolicismo carismático e política (Procópio, 2012; 2014), mostrando a ambivalência na qual o movimento está assentado, o que também tem mostrado a literatura internacional sobre o tema (Pina, 1997; 1999; 
Hunt, 2008). Por um lado, temos a valorização dos procedimentos políticos, quando alguns deputados vinculados à Renovação acionam dispositivos inerentes à burocracia do estado para atuarem e operarem suas funções e demandas. Por mais que essa prática possa obscurecer as razões últimas que esses políticos possuem no fazimento de seus mandatos, não se pode deixar de levar em conta que, ao operarem com os dispositivos legais, valorizam esta prática e a convertem em espaço de disputa de interesses. Essa prática deslocaria as ações baseadas nas razões últimas que se escondem por trás dos procedimentos para a execução e manejo dos próprios procedimentos. Por outro lado, temos a valorização de princípios cívicos e republicanos. Nesse caso, há valores a serem salvaguardados e que passam pela guarda de princípios democráticos, a defesa dos princípios constitucionais e o respeito pela soberania do voto. Os carismáticos têm, em muitos momentos da história recente do país, lançado mão desses valores que, por mais que consubstanciados com valores religiosos, ativa uma ideia de bem comum e um senso de coletividade (Procópio, 2012).

As posições de Odair Cunha e Gabriel Chalita, que resumiram suas ações dentro do espectro partidário no processo de impeachment, aponta para um quinto e último conjunto de forças. Os carismáticos têm se filiado a uma infinidade de partidos ao longo dos últimos 30 anos, mas que podemos separar em dois tipos de adesão bem consolidados quando olhamos para os deputados eleitos: os que se mantêm filiados de forma efetiva a um partido ou linha programática; os que mudam de partido dependendo dos interesses ou condição do partido em possibilitar projeção ${ }^{18}$. Odair representa o primeiro grupo, pois se mantém filiado ao PT desde o início de sua vida parlamentar. Chalita representa o segundo grupo, já que passou, desde o fim dos anos de 1980, por PDT, PSDB, PSB, PMDB até retornar ao PDT. Nos dois casos a questão partidária vai ser o epicentro de suas mobilizações ao longo do impeachment. Odair é utilizado por seu partido para realizar manobras em relação à quantidade de votos em defesa de Dilma. É exonerado de sua função executiva em Minas Gerais para fazer número na Câmara dos Deputados, mas é reempossado como secretário de estado tão logo esta presença deixar de fazer a diferença em termos quantitativos. Chalita se movimenta por cima das dinâmicas dos partidos para poder marcar sua posição. Ao não ver sua perspectiva reconhecida em seu partido, 0 PMDB, não reluta em mudar de legenda, abandonando o partido que passava

18 Dentre os deputados com experiência política citados nesse artigo, Molon e Odair se mantêm afinados a uma mesma linha político-partidária (centro-esquerda). Já os deputados Biondini, Zimbaldi e Chalita são exemplos de migração partidária, tendo passado em pelo menos 3 partidos com orientação diferente ao longo de suas carreiras. 
para a oposição de Dilma e se filiando ao PDT, "fiel" à presidenta. Claro que pesa nessa mudança a função de secretário de educação que exercia na prefeitura do petista Fernando Haddad, mas não se pode deixar de levar em conta afinidades com a gestão petista que podem ter justificado a decisão de Chalita ${ }^{19}$.

Ajuda a entender algumas das interfaces deputado-partido, a posição dos partidos em relação ao impeachment e a posição dos deputados em face da orientação dada. Assim, se tomarmos os vínculos partidários dos carismáticos à época da votação do impeachment e contrastarmos com as orientações dos líderes das bancadas a favor ou contra o impedimento de Dilma, encontramos um cenário de adesão partidária e afinidade programática bastante interessante. Dos partidos que não fecharam questão na votação da admissibilidade do processo contra a presidenta, dois possuíam deputados ligados a RCC, o PHS e o PROS. A bancada liberada permitiu que cada deputado votasse seguindo sua consciência e entendimento. Garcia (PHS) e Biondini (PROS) optaram pela posição favorável, enquanto Zimbaldi (PROS) não se pronunciou, decisões confortáveis diante das posições de suas legendas. O PT, a REDE e o PDT orientaram votar não, e a posição de seus quadros advindos do carismatismo católico seguiram na mesma direção. Molon (REDE) o fez no parlamento, enquanto Odair (PT) e Chalita, que saiu do PMDB (que liberou a bancada para votar) e se dirigiu para o PDT, fizeram-no em outros níveis. A mesma continuidade com a orientação partidária pode ser vista nos casos dos deputados que votaram sim. O PSB de Flavinho e o PV de Gussi tinham orientado suas bancadas a se posicionaram a favor do impedimento e suas posições no parlamento passaram longe de trair suas pertenças partidárias.

Contudo, não se pode resumir a afinidade entre deputados carismáticos e partidos apenas levando em conta as posições destes últimos em relação ao impeachment, pois as tensões nessa relação são parte do cotidiano da vida política desses deputados e tomam várias direções. Entretanto, não se pode desconsiderar que a participação em partidos políticos interfere na maneira como os carismáticos se inserem na política. Não estamos apenas diante de um quadro de relação instrumental, no qual a mensagem religiosa tem preponderância diante da ideologia partidária. Quando circulam por muitos partidos, podem o estar fazendo dentro daquelas legendas com baixa densidade ideológica, com exigências de pertencimento mínimo e que estão interessados em grande parte nos votos que o deputado ou postulante a cargo parlamentar pode possuir por

19 Chalita inclusive chegou a ser cogitado para ser ministro da educação tão logo se iniciou o segundo governo Dilma. 
conta de seus vínculos religiosos. Além do mais, é o próprio sistema eleitoral brasileiro que permite que a rotatividade dos quadros nos partidos seja expressiva, e os carismáticos não devem pensar duas vezes ao decidirem mudar de legenda, basta encontrarem limites e barreiras para sua atuação. Isso os leva a buscar como destino as legendas que lhes deem a possibilidade de manter sua posição parlamentar e/ou permita a ocupação de lugares de destaque dentro do partido e do parlamento. Por outro lado, ocorre casos nos quais a opção pelo partido se dá por afinidades mais ideológicas. Dependendo da formação política e das experiências no âmbito da vida pública, os políticos vinculados ao carismatismo católico acabam procurando as legendas cujas bandeiras eles se identificam. Essa relação cria um vínculo de longa data que dificulta uma separação fácil. Nos casos em que emergem tensões entre conviç̧ão pessoal e programa partidário, os carismáticos podem sofrer com as exigências das lideranças do partido, restando ou obediência ou a dissidência. Para superarem as diferenças, chegam inclusive a articular justificativa para o pertencimento que vão atestar as afinidades e dificultar as rupturas (Procópio, 2015).

\section{Conclusão}

Apesar de limitadas a algumas ações localizadas, este texto procurou valorizar os engajamentos políticos dos carismáticos durante a votação do impeachment de Dilma Rousseff, permitindo visualizar os engajamentos que eles desempenham na política e os conjuntos de forças pelas quais se engajam. Desse modo, antes que enquadramentos prévios que pudessem nortear o entendimento das práticas colocadas em jogo, estas é que são tomadas como balizadoras da análise, considerando as cenas que lhes deram publicidade. Isso permite com que os engajamentos políticos dos deputados carismáticos sejam vistos e compreendidos nos seus processos de feitura diária, deslocando pertenças rígidas e definitivas em benefício de desempenhos públicos mais difusos. No caso do impedimento de Dilma, cuja dramática também incidiu sobre o catolicismo carismático, seus deputados se mobilizaram para responder a esta situação problemática, fomentando agrupamentos e alinhavando conjuntos de força, mas também produziram engajamentos que respondem a demandas de mobilização política no interior do movimento católico com a qual mantém colaboração.

O engajamento no processo de votação do impeachment permite mostrar as várias frentes abertas pela inserção dos carismáticos católicos na política brasileira nos últimos anos. Na arena pública visualizada a partir da problemática do 
impedimento de Dilma, os carismáticos tiveram suas ações estimuladas pelas dinâmicas internas dos grupos e comunidades católicos com os quais se vinculavam. Garcia e Biondini votaram em nome da RCC e em parte estariam direcionando alguns interesses que atravessam grupos de comunidades católicas. O mesmo estímulo pode ser visto nas lógicas inerentes à valorização dos procedimentos políticos acionados por alguns de seus deputados. Flavinho e Molon levaram em conta o parecer que pedia a admissibilidade do impeachment e votaram levando em conta o saber-fazer parlamentar. Algumas ações também sofreram pressão das manifestações em espaços abertos que mobilizaram milhões de pessoas que se faziam como grupos de pressão sobre os deputados, mas também de reivindicação de representação por parte dos deputados. Gussi toma as ruas como motivador de sua posição e por ela se engaja, ao mesmo tempo assimilando os desejos das ruas e confundindo estes com os seus interesses políticos. Zimbaldi quis manter as aparências e, para assegurar o acesso a recursos públicos, evita se posicionar. Mas as ações dos carismáticos também foram impactadas pelas movimentações partidárias que forçavam a posição dos seus parlamentares e testavam sua fidelidade. Odair e Chalita se movimentaram dentro ou por cima dos partidos com os quais se vinculavam, tal como fizeram os demais políticos do carismatismo católico quando defrontados com as posições de seus partidos.

Se essas dinâmicas impactam na ação dos deputados, na medida em que podem ser vistas em cada movimento executado no púlpito, no parlamento, na rua ou no partido, a ação de cada deputado também impacta em cada uma destas esferas. A reivindicação por um jeito de fazer política no carismatismo católico fica expressa nas falas de Garcia e Biondini. Suas posições, para serem hegemônicas, vão produzir um debate sobre a qualidade da posição a ser tomada no interior de grupos e comunidades carismáticas. Mas, no parlamento, deputados como Flavinho e Molon operam dentro de uma base mais procedimental, valorizando o saber fazer político-institucional, dando outro parâmetro de atuação nesta esfera. Já na rua em que Gussi reivindica o lugar de fala e atua engrossando suas malhas, os carismáticos podem estar ajudando a pautar as bandeiras desses militantes ocasionais, cuja limitação programática faz com que discursos como os religiosos possam ser navegáveis pelas ondas produzidas. Mas não podemos esquecer que algumas relações são meramente instrumentais e a decisão de Zimbaldi em não mostrar abertamente sua posição é um balizador para esse tipo de comportamento no interior do carismatismo. $\mathrm{E}$ nos partidos, se casos como o de Odair mostram a possibilidade de afinidades e justaposições entre carismatismo e programas partidários, casos como o de 
Chalita apontam para uma relativização destes programas em benefício de interesses mais particulares.

\section{Referências}

ALMEIDA, Ronaldo. Os deuses do parlamento. Novos Estudos CEBRAP. São Paulo, Edição Especial, Junho de 2017, pp. 71-79.

ALONSO, Angela. A política das ruas: Protestos em São Paulo de Dilma a Temer. Novos Estudos CEBRAP. São Paulo, Edição Especial, Junho de 2017, pp. 49-58.

ANDRADE, Péricles; SOFIATI, Flávio M. Acorda Canção Nova!: conservadores católicos e eleições presidenciais em 2010. In: Coletânea História das Religiões no Brasil. v. 7. 1 ed. Recife-PE: Editora Universitária da UFPE e Associação de Imprensa de Pernambuco, 2016, pp. 55-77.

BURITY, Joanildo A.; MACHADO, Maria das Dores Campos. Os votos de Deus: evangélicos, política e eleições no Brasil. Fundação Joaquim Nabuco, Editora Massangana, 2005.

CARRANZA, Brenda. Renovação carismática católica: origens, mudança e tendências. Aparecida, Santuário, 2000.

CARRANZA, Brenda; MARIZ, Cecília Loreto; CAMURÇA, Marcelo Ayres. Novas comunidades católicas: em busca do espaço pós-moderno. Ideias \& Letras, 2009.

CEFAÏ, Daniel. Qu'est-ce qu'une arene publique? Quelques pistes pour une approche pragmatiste. In: CEFAÏ, Daniel.; JOSEPH, Isaac. (Dir.). L'Heritage du pragmatisme: conflits d'urbanité et épreuves de civisme. La Tour d'Aigues: Editions de l'Aube, 2002. . Como nos mobilizamos? A contribuição de uma abordagem pragmatista para a sociologia da ação coletiva. Dilemas: Revista de Estudos de Conflito e Controle Social. Rio de Janeiro, v. 2, n. 4, p. 11-48, abr./maio/jun. 2009.

DIAP. Radiografia do Novo Congresso: Legislatura 2015-2019. Departamento Intersindical de Assessoria Parlamentar. Brasília, DF, DIAP, 2014.

DUARTE, Luiz Fernando Dias. Valores cívicos e morais em jogo na câmara dos deputados: a votação sobre o pedido de impeachment da presidente da república. Religião e Sociedade. Rio de Janeiro, v. 37, n. 1, jan./jun. 2017, pp.145-166.

GOHN, Maria da Glória. Manifestações de protesto nas ruas no Brasil a partir de Junho de 2013: novíssimos sujeitos em cena. Rev. Diálogo Educ. Curitiba, v. 16, n. 47, jan./ abr. 2016, pp. 125-146.

HUNT, Stephen. Betwixt and between: the political orientations of roman catholic neoPentecostals. Politics and Religions. Belgrado, v. 2, n. 2, 2008, pp. 27-51.

IFFLY, Catherine. Transformar a metrópole: Igreja Católica, territórios e mobilizações sociais em São Paulo, 1970-20oo. São Paulo, Editora UNESP, 2011. 
LIMONGI, Fernando. Impedindo Dilma. Novos Estudos CEBRAP. São Paulo, Edição Especial, Junho de 2017, pp. 5-13.

MACHADO, Maria das Dores Campos. Política e religião: a participação dos evangélicos nas eleições. Rio de Janeiro, FGV Editora, 2006.

. Religião e Política no Brasil Contemporâneo: uma análise dos pentecostais e carismáticos católicos. Religião \& Sociedade. Rio de janeiro, v. 35, n. 2 2015. pp. 45-72.

MIRANDA, Julia. Carisma, sociedade e política. Rio de Janeiro, Relume Dumará, 1999. . Católicos carismáticos e as eleições municipais de 2012. Ciências Sociais Unisinos (Online). v. 51, n. 2, mai./ago. 2015, pp. 28-42.

MONTERO, Paula. "Religiões públicas" ou religiões na esfera pública? Para uma crítica ao conceito de campo religioso de Pierre Bourdieu. Religião e Sociedade. Rio de Janeiro, v. 36, n. 1, 2016, pp.128-150.

NÓBREGA, Camila. O olhar da imprensa internacional sobre o impeachment no Brasil. Carta Capital, 28 abr. 2016.

RIBEIRO DE OLIVEIRA, Pedro. A RC como agremiação religiosa. In: RIBEIRO DE OLIVEIRA, Pedro et alli. (org.) Renovação Carismática Católica: uma análise sociológica, interpretações teológicas. Petrópolis. Vozes, 1978.

. (org.) Fé e Política: fundamentos. São Paulo, Ideias e Letras, 2005.

OLIVEIRA, Eliane Martins. A vida no espírito e o dom de ser Canção Nova. In: CARRANZA, Brenda; MARIZ, Cecília Loreto; CAMURÇA, Marcelo Ayres. Novas comunidades católicas: em busca do espaço pós-moderno. Campinas, Ideias \& Letras, 2009.

ORO, Ari Pedro. Avanço pentecostal e reação católica. Petrópolis, Vozes, 1996.

PIMENTEL JR, Jairo. Impeachment, oposição e autoritarismo - o perfil e demanda dos manifestantes em São Paulo. Em Debate. Belo Horizonte, v. 7, n. 2, abr. 2015, pp. 15-22.

PINA, Christine. Religion et politique dans le "Renouveau charismatiques": le cas de deux communautés françaises. Religiologiques. Montreal, v. 16, set./dez. 1997, pp. 113-133.

. The City, the Countryside and Nature in the Discourse of Two Charismatic Revival Communities: Two Visions of Society and Politics? Social Compass. Louvain, v. 46, n. 1, mar.1999, pp. 85-99.

PINTO, Céli Regina Jardim. A trajetória discursiva das manifestações de rua no Brasil (2013-2015). Lua Nova. São Paulo, v. 100, 2017, pp. 119-153.

PORTELLA, Rodrigo. Renovação Carismática Católica: relações, interferências e tensões. Atualidade Teológica. Rio de Janeiro, v. 15, n. 39, 2011, pp. 644-657.

PRANDI, Reginaldo. Perto da magia e longe da política. In: PRANDI, Reginaldo; PIERUCCI, Antônio Flávio. A realidade social das religiões no Brasil. São Paulo, HUCITEC, 1996. 
. Um sopro do espírito. São Paulo: EdUSP, 1998.

PRANDI, Reginaldo; CARNEIRO, João Luiz. Em nome do pai: justificando votos dos deputados federais evangélicos e não evangélicos na abertura do impeachment de Dilma Rousseff. Revista Brasileira de Ciências Socias (RBCS). São Paulo, v. 33, n. 96, 2018, pp. 1-22.

PROCÓPIO, Carlos Eduardo Pinto. Carismatismo Católico e Eleições no Brasil. Ciencias Sociales y Religión. Porto Alegre v. 14, 2012, pp. 79-99.

_. Perto da Religião, Perto da Política: a participação do catolicismo carismático através da Instituição, Candidaturas e Mídia nas eleições de 2010. 2014. Tese de Doutorado em Ciências Sociais, PPGCSO/UFJF, Juiz de Fora, 2014.

. Quando a religião fica perto da política: o caso dos candidatos apoiados pelo catolicismo carismático nas eleições de 2014 no Brasil. Debates do NER. Porto Alegre, v. 1, n. 27, 2015, pp. 199-232.

. Catequistas, artistas ou socialmente engajados: as formas de inserção política do catolicismo carismático. Caminhos - Revista de Ciências da Religião. Goiânia, n. 1, V. 16,2018 , pp. 113-126.

REIS, Marcos Vinícius de Freitas; ALMEIDA, Fábio Py Murta de. Católicos carismáticos e seus projetos de leis parlamentares. In: SILVEIRA, Emerson Sena; MORAES JR, Manoel Ribeiro (Orgs). Religião, política e espaço público no Brasil. São Paulo, Fonte Editorial, 2015.

RIBEIRO, Gustavo Lins. Gramsci, Turner e Geertz - O Fim da Hegemonia do PT e o Golpe.R@U.São Carlos, v. 8, n. 2, jul./dez.2016, pp.11-19.

SILVA, Antônio Ozaí. Religião e Política: Memória e História da Renovação Carismática Católica em Maringá (PR). Revista Espaço Acadêmico. Maringá, n. 81, 2008.

SILVEIRA, Emerson José Sena da. Tradição e modernidade na renovação carismática católica: um estudo dos rituais, subjetividades e mito de origem. Juiz de Fora, UFJF, 2000 .

. Terços, 'Santinhos' e Versículos: a relação entre carismáticos católicos e política. Rever (PUCSP). São Paulo, v. 8, 2008, pp. 54-74.

Guerra Cultural Católica: política, espaço público e lideranças eclesiásticas. In: SILVEIRA, Emerson Sena; MORAES JR, Manoel Ribeiro (orgs). Religião, política e espaço público no Brasil. São Paulo, Fonte Editorial, 2015.

SINGER, André (org). Por que gritamos Golpe? Para entender o impeachment e a crise política no Brasil. Campinas, Boitempo, 2016.

SOUZA, Jessé. A radiografia do golpe: entenda como e por que você foi enganado. Leya, São Paulo, 2016.

VALLE, Edênio. A renovação carismática católica: algumas observações. Estudos Avançados. São Paulo, v. 18, n. 52, 2004, pp. 97-107. 
WEBER, Maria Helena et al., Manifestações e votos sobre impeachment de Dilma Rousseff na primeira página de jornais brasileiros. Revista Latinoamericana de Ciencias de la Comunicación. v. 13, n. 24, 2016, pp. 96-113.

Recebido em 29/20/2017 Aprovado em 30/05/2019

\section{Como citar este artigo:}

PROCÓPIO, Carlos Eduardo Pinto. O catolicismo carismático no impeachment de Dilma Rousseff. Contemporânea - Revista de Sociologia da UFSCar, v. 9, n. 1, jan.jun. 2019, pp. 275-299. 